\title{
A Study on the Impact of Logistics Service Quality on the Satisfaction and Loyalty of E-Shoppers in Egypt
}

\author{
Lobna Hafez, Eman Elakkad, Mohamed Gamil \\ College of International Transport and Logistics, Arab Academy for Science, Technology and Maritime Transport, Alexandria, \\ Egypt \\ Email: lobna.hafez@aast.edu, emanelakkad@aast.edu,mohamedgamil@aast.edu
}

How to cite this paper: Hafez, L., Elakkad, E., \& Gamil, M. (2021). A Study on the Impact of Logistics Service Quality on the Satisfaction and Loyalty of E-Shoppers in Egypt. Open Journal of Business and Management, 9, 2464-2478.

https://doi.org/10.4236/ojbm.2021.95133

Received: August 23, 2021

Accepted: September 20, 2021

Published: September 23, 2021

Copyright $\odot 2021$ by author(s) and Scientific Research Publishing Inc. This work is licensed under the Creative Commons Attribution International License (CC BY 4.0).

http://creativecommons.org/licenses/by/4.0/ (c) (i) Open Access

\begin{abstract}
Customers nowadays are increasingly using online shopping due to its convenience in terms of time and cost, in addition to providing a vast variety of products and services and allowing customer to compare between different products. Several factors can affect the satisfaction levels of online customers including the quality of logistics services. This paper studies the relationship between logistics service quality (LSQ) dimensions and customer satisfaction and then studies the impact of customer satisfaction on customer loyalty. The study targeted online shoppers in Egypt and 292 responses were collected. The findings of the study revealed that information quality, product quality, product condition and reverse logistics are the most significant variable relating to customer satisfaction and that customer satisfaction has a significant impact on customer loyalty. This study can help online retailers in identifying areas of improvements to achieve higher levels of customer satisfaction.
\end{abstract}

\section{Keywords}

Logistics Services Quality, Online Shopping, Satisfaction, Loyalty

\section{Introduction}

Nowadays, online shopping is an easy solution for busy life, enabling products and services to be sold to internet users around the world. Online shopping is a type of electronic commerce (Rajendran, Wahab, Ling, \& Yun, 2018) which has exceptional characteristics (Rahman, Islam, Esha, Sultana, \& Chakravorty, 2018). Online shopping is the shift of having physical shopping to virtual shopping using virtual online stores. In other words, no physical space is needed to shop. In 
online stores, all goods should have full description through text or photos.

The Internet plays an important role in online shopping, as well as, technologies. Online stores provide extra links for their products. Consumers can buy products or services by using their smartphones, tablets or computers. Consumers can find full information and others' reviews about the product. Online shopping has much more ease in product accessibility, timeless, perceived risk, product varieties which impact buying intention (Selvaraju \& Karthikeyan, 2016). Online consumers can compare the products' prices and quality, and can purchase products at a reduced rate in comparison to the traditional shops. Online shops have lower operation costs, operational hours, physical space and geography than the physical shops. Minimizing costs is reflected on the products prices.

Online retailers started to find improved ways to attract customers and support their online operation. Different studies were conducted on the impact of website effectiveness towards online satisfaction and repurchase intention (Hong, Farha, Zulkifli, \& Hamsani, 2017; Luo, Ba, \& Zhang, 2012).

In Egypt, despite the rapid growth of the number of internet users, online shopping is still at the early stage of development. There is a deficiency of knowledge concerning the online shopping and the influencing factors of the Egyptian behavior for adopting the online shopping needs to be observed. Strong Information and Communications Technology (ICT) infrastructure, qualified human resources, logistics discriminates Egypt -due to its location and innovation are the main factors of online shopping that enhance the companies' competitiveness (El Gohary, 2019). Companies in Egypt face many challenges and obstacles when applying online shopping like, the lack of infrastructures and logistics in rural areas, absence of the online shopping awareness, fear of having e-payments (Aref \& Okasha, 2020).

This study investigates the impact of logistics service quality (LSQ) on customers' satisfaction and loyalty. Several researchers have studied LSQ dimensions; however, limited studies exist in Egypt. Therefore, there is a need for more studies in this area. This study is an attempt to help online retailers in Egypt to improve their customer satisfaction and loyalty levels through answering the following questions: 1) what is the relationship between LSQ dimensions and customer satisfaction and loyalty? 2) which LSQ dimensions have the greatest effect customers' satisfaction and loyalty? The study focuses on the current and potential online shoppers and taking into consideration the levels of education and the level of income.

The paper is divided into six main sections that are introduction, literature review, research model and hypotheses, methodology, results and analysis and finally the conclusion.

\section{Literature Review}

\subsection{Online Shopping Logistics Service Quality}

Logistics Service Quality (LSQ) is defined as a set of performance factors, meas- 
ured by the ability to distribute products in accordance with customer requirements (Yang, Hui, Leung, \& Chen, 2010). Online shopping logistics spans from the order placement to final product delivery (Choi, Chung, \& Young, 2019). Several LSQ dimensions were investigated in the literature; Table 1 presents a summary of the literature findings.

Based on the literature review conducted, information quality, product quality, delivery service, customer service, order condition and reverse logistics were found to have the strongest effect on customer satisfaction as concluded from the previously mentioned studies. Therefore, these factors will be considered as the determinants of LSQ in this study.

\subsection{Customer Satisfaction}

Satisfaction is one of the most important success measures in the business, Customer satisfaction is defined as an indication of the customer's belief of the probability of a service leading to a positive feeling, customer satisfaction is the consequence of customer experiences during the buying process, and it plays a crucial role in affecting customers' future behavior, such as online repurchase and loyalty (Pereira, Salgueiro, \& Rita, 2016).

Customers tend to be satisfied with online shopping when service quality attributes deemed most important are met or surpassed (Kong \& Chow, 2015). The biggest challenge for online shopping is that the company has to provide a decent service experience to customers (Hult, Sharma, Morgeson, \& Zhang, 2019).

Table 1. Logistics service quality dimensions.

\begin{tabular}{|c|c|}
\hline Reference & LSQ dimensions \\
\hline $\begin{array}{l}\text { (Revindran, Ragen, \& Mahmud, } \\
\text { 2020) }\end{array}$ & $\begin{array}{l}\text { Timeliness, product availability, product condition and reverse } \\
\text { logistics. }\end{array}$ \\
\hline (Choi et al., 2019) & $\begin{array}{l}\text { Quality of information, quality of delivery, quality of order, price } \\
\text { of delivery and customer service. }\end{array}$ \\
\hline (Rajendran et al., 2018) & $\begin{array}{l}\text { Delivery services, reverse logistics, product quality, customer } \\
\text { service and service recovery. }\end{array}$ \\
\hline (Alemu, 2016) & $\begin{array}{l}\text { Information quality, ordering procedure, timeliness, order } \\
\text { condition, order accuracy, order discrepancy handling and } \\
\text { personal contact quality. }\end{array}$ \\
\hline (Yoon, 2011) & $\begin{array}{l}\text { Quality of the order, the quality of delivery, customer service, and } \\
\text { the delivery price. }\end{array}$ \\
\hline (Lee, Park, \& Park, 2008) & $\begin{array}{l}\text { Speed of delivery, accuracy of the delivery system, safety of } \\
\text { delivery, ease of delivery, and personality of the delivery person. }\end{array}$ \\
\hline (Feng, Zheng, \& Tan, 2007) & $\begin{array}{l}\text { Timeliness, personal contact quality, order quality, order } \\
\text { discrepancy handling, order condition and convenience. }\end{array}$ \\
\hline (Mentzer, Flint, \& Hult, 2001) & $\begin{array}{l}\text { Order placement, personnel contact quality, order release } \\
\text { quantities, information quality, ordering procedures, order } \\
\text { receipt, order accuracy, order condition, order quality, order } \\
\text { discrepancy handling and timeliness. }\end{array}$ \\
\hline
\end{tabular}


Satisfied online customers are expected to shop again and recommend online retailers to others. Satisfaction is closely related to customer attitudes and intentions, which are part of customer behavior and affect customers' positive behavioral intentions (Pereira et al., 2016). Online customer satisfaction is the key to the buying behavior of the future. Customers who are satisfied with the service provided by a service provider would increase the usage level and future loyalty (Rita, Oliveira, \& Farisa, 2019).

For these reasons, online Shopping systems allow customers to customize the screening, pre-purchase, search process, reducing costs associated with future purchases, and increasing customer confidence and loyalty. Many studies have confirmed a significant relationship between online service quality and customer satisfaction (Blut, Frennea, Mittal, \& Mothersbaugh, 2015; Rajendran et al., 2018; Rita et al., 2019).

\subsection{Customer Loyalty}

Customer loyalty or the intention of the buyer to repurchase from the retailer is considered as a direct consequence of customer satisfaction (Bi, 2019). Many of studies state that customer satisfaction plays a stronger role in determining the online customer loyalty and an important role in motivating customers' loyalty which interprets into giving positive reviews, repeat purchasing or recommending the product or service to others (Odunlami, 2015; Waari, 2019; Zhang, Guo, $\mathrm{Hu}, \& \mathrm{Liu}, 2017)$. Studies have also shown that online customer satisfaction positively influences online customer loyalty (Martin, Mortimer, \& Andrews, 2015; Rose, Clark, Samouel, \& Hair, 2012).

\section{Research Model and Hypothesis}

The research aims to study the effect of logistics service quality of online shopping services in Egypt on the customer satisfaction and customer loyalty and proposes hypotheses based on the research model illustrated in Figure 1.

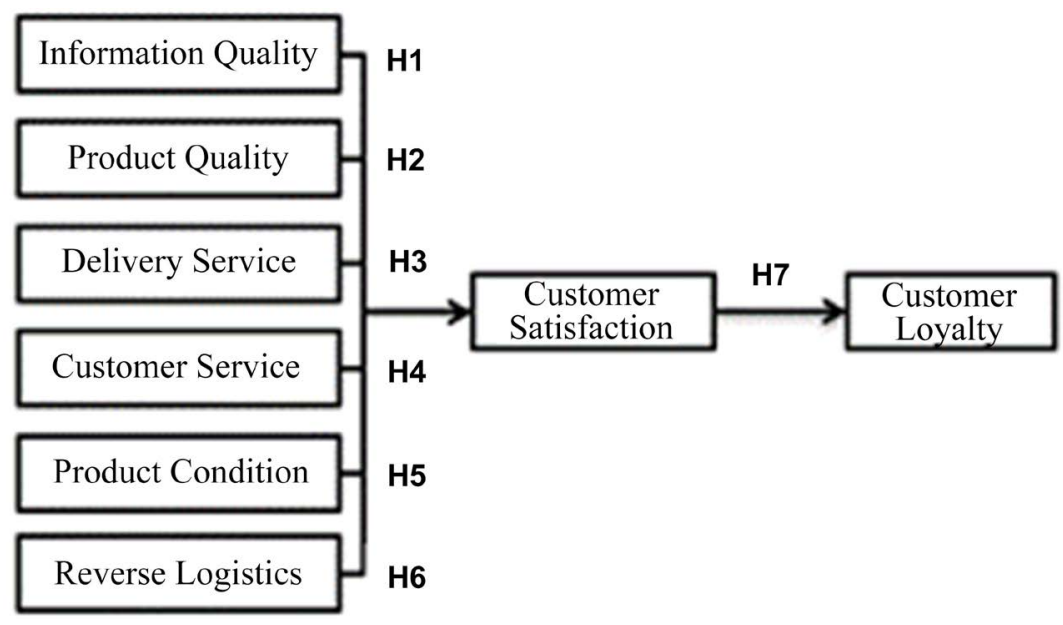

Figure 1. The research conceptual model. 
H1: There is a significant relationship between information quality and customer satisfaction

H2: There is a significant relationship between product quality and customer satisfaction

H3: There is a significant relationship between delivery service and customer satisfaction

H4: There is a significant relationship between customer service and customer satisfaction

H5: There is a significant relationship between product condition and customer satisfaction

H6: There is a significant relationship between reverse logistics and customer satisfaction

H7: There is a significant relationship between customer satisfaction and customer loyalty

\subsection{Information Quality}

Quality of information in online shopping refers to "the ease and accessibility of the product search and location" (Choi et al., 2019), in addition to the availability of reliable information about the product price and specification. (Alemu, 2016) stated that information quality reflects how the customer perceives the information provided by the online retailer about products that customer can purchase. She concluded that there is a significant positive relationship between information quality and customer satisfaction. This result was also confirmed by Choi et al. (2019).

\subsection{Product Quality}

Product quality refers to the product ability to satisfy customer's needs and meet his expectations (Hondoko, 2016). Product quality is considered as the foundation to build customer satisfaction (Bei \& Chiao, 2001). Product quality encourages customers to increase their use of online shopping (Olasanmi, 2019) and has a positive impact on customer satisfaction (Hondoko, 2016; Razak, Nirwanto, \& Triatmanto, 2016). Product quality is assessed through the following measures: the similarity of the product quality to products purchased in store (Vasic, Kilibarda, \& Kaurin, 2019) and the availability of real reviews on product quality.

\subsection{Customer Service}

Customer service refers to how responsive is the online retailer in responding to customer request (Rajendran et al., 2018). The level of customer service can affect customers purchasing decision (Kaňovská, 2010) and eventually their level of satisfaction. Customer service includes the after-sales support or other logistics services performed on behalf of the customer upon completion of a transaction (Choi et al., 2019). Liu, He, Gao, \& Xie (2008) revealed that customer ser- 
vice has a positive impact on customer satisfaction; this result was also confirmed by Rajendran et al. (2018). Customer service is assessed in terms of the ease of reaching customer service, the contact personnel quality and the ability to solve customer problems.

\subsection{Delivery Service}

According to (Hedin, Jonsson, \& Ljunggren, 2006) delivery service is considered as the driver of customer satisfaction. Delivery service refers to the capability of the supplier to provide customers with the required product within the desired lead-time in the desired place and with minimum expenses (Vasic et al., 2019). Ziaullah, Feng, \& Akhter (2014) and (Hondoko, 2016) concluded that delivery service has a positive effect on online customer satisfaction. The delivery service will be assessed in terms of commitment to lead time announced to the customer, its accuracy regarding the place of delivery and the cost of the delivery service. Customers can be charged additional charges for delivery which makes the final product price similar to or higher than offline prices (Choi et al., 2019).

\subsection{Order Condition}

Order condition refers to the ability of the online retailer to deliver products to customers without any damage. Revindran et al. (2020) determined that there is a positive relationship between order condition and online customer satisfaction. According to Alemu (2016) there is a positive relationship between order condition and customer satisfaction. Order condition is assessed in terms the receipt of undamaged orders either due to poor transportation or handling.

\subsection{Reverse Logistics}

Reverse logistics refers to the aftermarket transactions which is responsible for managing the returns from customer due to disproportionate criteria from the customers' perspective (Rajendran et al., 2018). The proper management of customer returns helps to improve customer service (Lysenko-Ryba, 2017). As Revindran et al. (2020) stated, reverse logistics have a significant effect on the satisfaction of online shoppers. The reverse logistics will be assessed in terms of the ease of making returns, the availability of a clear return policy and the return fees (Cao, Ajjan, \& Hong, 2018).

\section{Research Methodology}

In this research, a quantitative approach is applied to assess the relationship between the variables under investigation. The research is based on secondary and primary data; secondary data was collected from published articles and websites, while the primary data was collected through using a structured online questionnaire. Using previous studies, the questionnaire was designed, the first part constitutes questions to reflect the socio demographic profile of each respondent, then the next part consisted of five-point Likert scale questions, 1 is 
strongly disagree and 5 is strongly agree, were used to assess the level of agreement of the respondents on each statement representing the research variables. The questionnaire was distributed to a sample of the Egyptian population. Non probability sampling was used to fit the purpose of the study, convenience sampling technique was selected. According to formula applied to determine the sample size using 95\% confidence level, the sample size should be 385 , however a total of 292 responses were collected, the sample size was seen adequate to represent the population as sample sizes ranging from 30 to 500 were seen as appropriate samples in the literature (Rajendran et al., 2018). The analysis was done through using SPSS software.

\section{Results and Data Analysis}

The data was analyzed using descriptive analysis, reliability test, correlation analysis and regression analysis. The descriptive analysis was used to illustrate the social demographic profile of the respondents (Table 2). 112 men (38.4\%) and 180 women $(61.6 \%)$ participated in the survey. The age distribution was 6 respondents below $20(2.1 \%), 130$ respondents from 20 to 30 (44.5\%), 102 respondents from 31 to 40 (34.9\%) and 54 respondents above 40 (18.5\%).

Table 2. Social demographic profile.

\begin{tabular}{|c|c|c|}
\hline Social demographic profile & $\mathbf{N}$ & $\%$ \\
\hline \multicolumn{3}{|l|}{ Gender } \\
\hline Male & 112 & 38.4 \\
\hline Female & 180 & 61.6 \\
\hline Total & 292 & 100.0 \\
\hline \multicolumn{3}{|l|}{ Age } \\
\hline Below 20 & 6 & 2.1 \\
\hline $20-30$ & 130 & 44.5 \\
\hline $31-40$ & 102 & 34.9 \\
\hline Above 40 & 54 & 18.5 \\
\hline Total & 292 & 100.0 \\
\hline \multicolumn{3}{|l|}{ Occupation } \\
\hline Student & 43 & 14.7 \\
\hline Employed & 167 & 57.2 \\
\hline Unemployed & 82 & 28.1 \\
\hline Total & 292 & 100.0 \\
\hline \multicolumn{3}{|l|}{ Education } \\
\hline Secondary school or below & 7 & 2.4 \\
\hline University & 184 & 63.0 \\
\hline Masters or Doctoral studies & 101 & 34.6 \\
\hline Total & 292 & 100.0 \\
\hline
\end{tabular}




\section{Continued}

\begin{tabular}{lcc}
\hline Income & & \\
Below 2000 & 41 & 14.0 \\
From 2000 to less than 5000 & 88 & 30.1 \\
From 5000 to less than 8000 & 51 & 17.5 \\
More than 8000 & 112 & 38.4 \\
Total & 292 & 100.0 \\
\hline
\end{tabular}

Regarding the education level, 7 respondents were in secondary school or below (2.4\%), 184 respondents were university graduates (63\%) and 101 respondents were masters or $\mathrm{PhD}$ holders (34.6\%).

The distribution of the occupation was 43 students (14.7\%), 167 employed (57.2) and 82 unemployed (28.1\%). The income percentages were recorded as follows, 41 respondents below 2000 EGP (14\%), 88 respondents income were from 2000 to less 5000 (30.1\%), 51 respondents from 5000 to less than 8000 (17.5\%) and 112 respondents' income was above 8000 (38.4\%).

The results of the survey indicated that the majority of respondents make online purchases once a month with a percentage of 57.5\%. Social media pages ranked first when participants were asked about the most preferred online stores with a percentage of $40.4 \%$. Regarding the products categories which are purchased online the most, clothes and shoes ranked first with $42.5 \%$. The purchasing behavior results are illustrated in Table 3.

\subsection{Reliability Test}

Reliability refers to the consistency of a measure, the three attributes of reliability are homogeneity which refers to the extent to which the items of a scale measure one construct, stability which refers to the consistency of the results with repeated testing and equivalence which refers to the consistency of the measure among responses of multiple users of an instrument (Heale \& Twycross, 2015). According to Hulin, Netemeyer, \& Cudeck (2001) Cronbach alpha above 0.6 is an acceptable level of reliability. In this study all items were found to have coefficient higher than 0.6 , the total degree of reliability is 0.893 (Table 4).

\subsection{Correlation Analysis}

Pearson's correlation analysis has been used to test the relationship between the independent variables and the dependent variables. The value of $r$ (coefficient of correlation) is only allowed to change between +1 and $-1 .+1$ indicates that there is a positive relationship between the dependent and independent variable and -1 indicates a negative relationship. According to Guilford interpretation of the magnitude of correlation, a relationship is moderate when it falls between 0.41 and 0.70 and the relationship is strong when it falls between 0.71 and 0.90 (Van Aswegen \& Engelbrecht, 2009). 
Table 3. Respondents' purchasing behavior.

\begin{tabular}{|c|c|c|}
\hline Description & $\mathbf{N}$ & $\%$ \\
\hline \multicolumn{3}{|l|}{ Frequency of online shopping } \\
\hline Once a month & 168 & 57.5 \\
\hline 2 - 3 times per month & 85 & 29.1 \\
\hline More than 3 times & 39 & 13.4 \\
\hline Total & 292 & 100.0 \\
\hline \multicolumn{3}{|c|}{ Which of the following is your most preferred store when shopping online } \\
\hline Amazon & 37 & 12.7 \\
\hline Souq & 76 & 26.0 \\
\hline Jumia & 13 & 4.5 \\
\hline Social media pages & 118 & 40.4 \\
\hline Brand website & 2 & .7 \\
\hline Others & 46 & 15.8 \\
\hline Total & 292 & 100.0 \\
\hline \multicolumn{3}{|c|}{ From the shopping categories listed, which type do you buy the most? } \\
\hline Electric goods & 17 & 5.8 \\
\hline Smart phones and laptops & 14 & 4.8 \\
\hline Clothes and shoes & 124 & 42.5 \\
\hline Accessories & 25 & 8.6 \\
\hline Cosmetics & 26 & 8.9 \\
\hline Others & 86 & 29.5 \\
\hline Total & 292 & 100.0 \\
\hline
\end{tabular}

Table 4. Summary of the reliability test.

\begin{tabular}{ccc}
\hline Variables & Cronbach's alpha & No of items \\
\hline Information quality & 0.793 & 3 \\
Product quality & 0.692 & 2 \\
Delivery service & 0.831 & 7 \\
Product condition & 0.835 & 3 \\
Customer service & 0.822 & 4 \\
Reverse logistics & 0.839 & 4 \\
Customer satisfaction & 0.921 & 5 \\
Customer loyalty & 0.957 & 6 \\
\hline
\end{tabular}

As shown in Table 5, the correlation results indicated a positive moderate relationship between all the service quality dimensions and customer satisfaction as follow: information quality (0.519), product quality (0.547), delivery service (0.470), product condition (0.467), customer service (0.470) and reverse logistics (0.506). As shown in Table 6, there is a positive strong correlation between customer satisfaction and customer's loyalty with a correlation coefficient of (0.792). 
Table 5. Correlations results between LSQ dimensions and customer satisfaction.

\begin{tabular}{|c|c|c|c|c|c|c|c|c|}
\hline \multicolumn{9}{|c|}{ Correlations } \\
\hline & & IQ & PQ & DS & $\mathrm{PC}$ & CS & $\mathrm{RL}$ & CSat \\
\hline \multirow{3}{*}{ IQ } & Pearson Correlation & 1 & $0.602^{* *}$ & $0.455^{* *}$ & $0.382^{* *}$ & $0.433^{* *}$ & $0.379^{\star *}$ & $0.519^{* *}$ \\
\hline & Sig. (2-tailed) & & 0.000 & 0.000 & 0.000 & 0.000 & 0.000 & 0.000 \\
\hline & $\mathrm{N}$ & 292 & 292 & 292 & 292 & 292 & 292 & 292 \\
\hline \multirow{3}{*}{ PQ } & Pearson Correlation & $0.602^{\star *}$ & 1 & $0.534^{\star *}$ & $0.445^{\star \star}$ & $0.439^{\star \star}$ & $0.485^{\star \star}$ & $0.547^{\star *}$ \\
\hline & Sig. (2-tailed) & 0.000 & & 0.000 & 0.000 & 0.000 & 0.000 & 0.000 \\
\hline & $\mathrm{N}$ & 292 & 292 & 292 & 292 & 292 & 292 & 292 \\
\hline \multirow{3}{*}{ DS } & Pearson Correlation & $0.455^{\star \star}$ & $0.534^{\star *}$ & 1 & $0.448^{\star *}$ & $0.646^{\star *}$ & $0.655^{\star \star}$ & $0.470^{* *}$ \\
\hline & Sig. (2-tailed) & 0.000 & 0.000 & & 0.000 & 0.000 & 0.000 & 0.000 \\
\hline & $\mathrm{N}$ & 292 & 292 & 292 & 292 & 292 & 292 & 292 \\
\hline \multirow{3}{*}{ PC } & Pearson Correlation & $0.382^{\star *}$ & $0.445^{\star *}$ & $0.448^{* *}$ & 1 & $0.412^{\star *}$ & $0.394^{\star *}$ & $0.467^{* *}$ \\
\hline & Sig. (2-tailed) & 0.000 & 0.000 & 0.000 & & 0.000 & 0.000 & 0.000 \\
\hline & $\mathrm{N}$ & 292 & 292 & 292 & 292 & 292 & 292 & 292 \\
\hline \multirow{3}{*}{ CS } & Pearson Correlation & $0.433^{\star *}$ & $0.439^{\star *}$ & $0.646^{* *}$ & $0.412^{\star *}$ & 1 & $0.561^{\star *}$ & $0.470^{* *}$ \\
\hline & Sig. (2-tailed) & 0.000 & 0.000 & 0.000 & 0.000 & & 0.000 & 0.000 \\
\hline & $\mathrm{N}$ & 292 & 292 & 292 & 292 & 292 & 292 & 292 \\
\hline \multirow{3}{*}{$\mathrm{RL}$} & Pearson Correlation & $0.379^{\star *}$ & $0.485^{\star *}$ & $0.655^{\star *}$ & $0.394^{\star *}$ & $0.561^{\star \star}$ & 1 & $0.506^{* *}$ \\
\hline & Sig. (2-tailed) & 0.000 & 0.000 & 0.000 & 0.000 & 0.000 & & 0.000 \\
\hline & $\mathrm{N}$ & 292 & 292 & 292 & 292 & 292 & 292 & 292 \\
\hline \multirow{3}{*}{ CSat } & Pearson Correlation & $0.519^{* *}$ & $0.547^{* *}$ & $0.470^{* *}$ & $0.467^{\star *}$ & $0.470^{\star *}$ & $0.506^{* *}$ & 1 \\
\hline & Sig. (2-tailed) & 0.000 & 0.000 & 0.000 & 0.000 & 0.000 & 0.000 & \\
\hline & $\mathrm{N}$ & 292 & 292 & 292 & 292 & 292 & 292 & 292 \\
\hline
\end{tabular}

${ }^{* *}$ Correlation is significant at the 0.01 level (2-tailed).

Table 6. Correlation results between customer satisfaction and customer loyalty.

\begin{tabular}{|c|c|c|c|}
\hline \multicolumn{4}{|c|}{ Correlations } \\
\hline & & CSat & $\mathrm{CL}$ \\
\hline \multirow{3}{*}{ CSat } & Pearson Correlation & 1 & $0.792^{\star *}$ \\
\hline & Sig. (2-tailed) & & 0.000 \\
\hline & $\mathrm{N}$ & 292 & 292 \\
\hline \multirow{3}{*}{$\mathrm{CL}$} & Pearson Correlation & $0.792^{\star *}$ & 1 \\
\hline & Sig. (2-tailed) & 0.000 & \\
\hline & $\mathrm{N}$ & 292 & 292 \\
\hline
\end{tabular}

${ }^{* *}$ Correlation is significant at the 0.01 level (2-tailed).

\subsection{Regression}

Regression analysis aims to explain the impact of changes in the independent variables on the dependent variable. Table 7 shows the results of regression, the 
logistics services quality dimensions were treated as the independent variable and the customer satisfaction as the dependent variable. Four independent variables have significant value less than 0.05 , which means that the respondents believe that these variables can have an effect on their satisfaction. The significant level of information quality $(p=0.000)$, product quality $(p=0.001)$, product condition $(p=0.001)$ and reverse logistics $(p=0.001)$.

Beta coefficient explained the relative importance of the factors in terms of their contribution to the variance. Of the four factors, information quality carried the heaviest weight $(\beta=0.212)$, followed by reverse logistics $(\beta=0.211)$, product quality $(\beta=0.201)$ and product condition $(\beta=0.178)$.

Based on Table 8, it can be concluded that $\mathrm{F}$ is significant $<0.05$ which means that there is a significant influence of reverse logistics, information quality, product condition, customer service, product quality and delivery service on customer satisfaction. According to Table 9, R square (coefficient of determination) is equal to 0.44 or $44 \%$ which means that the ability of the independent variables to explain the dependent variable is $44 \%$.

Customer satisfaction was found to have a positive significant effect on customer's loyalty $(p=0.000)$ as shown in Table 10 , the $\mathrm{R}$ square shows the ability of customer satisfaction to contribute to customer loyalty with a percentage of $62.5 \%$ (Table 11).

Table 7. Regression analysis results.

\begin{tabular}{|c|c|c|c|c|c|c|}
\hline \multicolumn{7}{|c|}{ Coefficients $^{\mathrm{a}}$} \\
\hline & \multirow[t]{2}{*}{ Model } & \multicolumn{2}{|c|}{$\begin{array}{c}\text { Unstandardized } \\
\text { Coefficients }\end{array}$} & \multirow{2}{*}{$\begin{array}{c}\begin{array}{c}\text { Standardized } \\
\text { Coefficients }\end{array} \\
\text { Beta }\end{array}$} & \multirow[t]{2}{*}{$\mathrm{t}$} & \multirow[t]{2}{*}{ Sig. } \\
\hline & & B & Std. Error & & & \\
\hline \multirow{7}{*}{1} & (Constant) & 0.339 & 0.251 & & 1.347 & 0.179 \\
\hline & IQ & 0.251 & 0.068 & 0.212 & 3.720 & 0.000 \\
\hline & PQ & 0.202 & 0.061 & 0.201 & 3.298 & 0.001 \\
\hline & DS & -0.027 & 0.068 & -0.027 & -0.394 & 0.694 \\
\hline & PC & 0.209 & 0.061 & 0.178 & 3.440 & 0.001 \\
\hline & CS & 0.119 & 0.062 & 0.116 & 1.913 & 0.057 \\
\hline & RL & 0.199 & 0.058 & 0.211 & 3.453 & 0.001 \\
\hline
\end{tabular}

a Dependent Variable: CSat.

Table 8. F test result.

\begin{tabular}{ccccccc}
\hline \multicolumn{7}{c}{ ANOVA $^{\mathrm{a}}$} \\
\hline \multicolumn{1}{c}{ Model } & Sum of Squares & df & Mean Square & F & Sig. \\
\hline & Regression & 145.392 & 6 & 24.232 & 39.114 & $<0.001^{\text {b }}$ \\
1 & Residual & 176.567 & 285 & 0.620 & & \\
& Total & 321.959 & 291 & & & \\
\hline
\end{tabular}

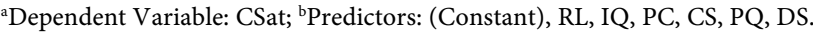


Table 9. Coefficient of determination examination result.

\begin{tabular}{ccccc}
\hline \multicolumn{5}{c}{ Model Summary } \\
\hline Model & $\mathrm{R}$ & R Square & Adjusted R Square & Std. Error of the Estimate \\
\hline 1 & $0.672^{\mathrm{a}}$ & 0.452 & 0.440 & 0.78710 \\
\hline
\end{tabular}

apredictors: (Constant), RL, IQ, PC, CS, PQ, DS.

Table 10. Regression results between customer satisfaction and loyalty.

\begin{tabular}{|c|c|c|c|c|c|c|}
\hline \multicolumn{7}{|c|}{ Coefficients $^{\mathrm{a}}$} \\
\hline & \multirow{2}{*}{ Model } & \multicolumn{2}{|c|}{ Unstandardized Coefficients } & \multirow{2}{*}{$\begin{array}{c}\begin{array}{c}\text { Standardized } \\
\text { Coefficients }\end{array} \\
\text { Beta }\end{array}$} & \multirow{2}{*}{$\mathrm{t}$} & \multirow{2}{*}{ Sig. } \\
\hline & & B & Std. Error & & & \\
\hline \multirow{2}{*}{1} & (Constant) & 1.023 & 0.138 & & 7.406 & 0.000 \\
\hline & CSat & 0.762 & 0.035 & 0.792 & 22.057 & 0.000 \\
\hline
\end{tabular}

apependent Variable: CL.

Table 11. Coefficient of determination results (customer satisfaction and customer loyalty).

\begin{tabular}{ccccc}
\hline \multicolumn{4}{c}{ Model Summary } \\
\hline Model & $\mathrm{R}$ & R Square & Adjusted R Square & Std. Error of the Estimate \\
\hline 1 & $0.792^{\mathrm{a}}$ & 0.627 & 0.625 & 0.62010 \\
\hline
\end{tabular}

apredictors: (Constant), CSat.

\section{Conclusion}

The study aimed to investigate the relation between LSQ dimensions and customer satisfaction and how customer satisfaction can influence customer loyalty. There is a lack of research in the area of LSQ and online shopping in Egypt; therefore this study extends the understanding of this area. The most influencing LSQ dimensions were selected from the literature. Six hypotheses were established to assess the relationship between LSQ dimensions represented in information quality, product quality, delivery service, product condition, customer service and reverse logistics. Another hypothesis was established to determine the impact of customer satisfaction on customer loyalty. The results showed that information quality, product quality, product condition and reverse logistics are the most significant variables related to customer satisfaction. Customer satisfaction has a significant influence on customer loyalty as well. Online retailers should work on improving their LSQs dimension. They should provide customer with more accurate and clear information on the displayed products. A clear returns policy should be announced explaining the obligations of each part to avoid any misunderstanding and complaints. Retailers should focus on their logistics services including warehousing and transportation in order to reduce losses and damage of product either during storage or transit. 


\section{Conflicts of Interest}

The authors declare no conflicts of interest regarding the publication of this paper.

\section{References}

Alemu, H. (2016). Implication of Logistics Service Quality on Customer Satisfaction: The Case of Jumia Online Market Addis Ababa, Ethiopia (pp. 43-44). http://etd.aau.edu.et/bitstream/handle/123456789/6589/HanaAlemu.pdf?sequence=1\&i sAllowed $=y$

Aref, M. M., \& Okasha, A. E. (2020). Evaluating the Online Shopping Behavior among Egyptian College-Educated Community. Review of Economics and Political Science, 5, 21-37. https://doi.org/10.1108/REPS-10-2018-0013

Bei, L.-T., \& Chiao, Y.-C. (2001). An Integrated Model for the Effects of Perceived Product, Perceived Service Quality, and Perceived Price Fairness on Consumer Satisfaction and Loyalty. Journal of Consumer Satisfaction, Dissatisfaction and Complaining Behavior, 14, 125-140.

Bi, Q. (2019). Cultivating Loyal Customers through Online Customer Communities: A Psychological Contract Perspective. Journal of Business Research, 103, 34-44. https://doi.org/10.1016/j.jbusres.2019.06.005

Blut, M., Frennea, C. M., Mittal, V., \& Mothersbaugh, D. L. (2015). How Procedural, Financial and Relational Switching Costs Affect Customer Satisfaction, Repurchase Intentions, and Repurchase Behavior: A Meta-Analysis. International Journal of Research in Marketing, 32, 226-229. https://doi.org/10.1016/j.ijresmar.2015.01.001

Cao, Y., Ajjan, H., \& Hong, P. (2018). Post-Purchase Shipping and Customer Service Experiences in Online Shopping and Their Impact on Customer Satisfaction: An Empirical Study with Comparison. Asia Pacific Journal of Marketing and Logistics, 30, 400-416. https://doi.org/10.1108/APJML-04-2017-0071

Choi, D., Chung, C. Y., \& Young, J. (2019). Sustainable Online Shopping Logistics for Customer Satisfaction and Repeat Purchasing Behavior: Evidence from China. Sustainability (Switzerland), 11, 1-20. https://doi.org/10.3390/su11205626

El Gohary, E. (2019). The Reality of E-Commerce in Egypt and Its Role in Enhancing Companies' Competitiveness. International Conference on E-Democracy, e-Government and e-Society, Paris, 24-25 February 2019.

https://www.researchgate.net/publication/331312564 The Reality of E-commerce in Egypt and its Role in Enhancing_Companies' Competitivenessv waq_altjart_alal

Feng, Y. X., Zheng, B., \& Tan, J. R. (2007). Exploratory Study of Logistics Service Quality Scale Based on Online Shopping Malls. Journal of Zhejiang University: Science A, 8 , 926-931. https://doi.org/10.1631/jzus.2007.A0926

Heale, R., \& Twycross, A. (2015). Validity and Reliability in Quantitative Studies. Evidence-Based Nursing, 18, 66-67. https://doi.org/10.1136/eb-2015-102129

Hedin, J., Jonsson, M., \& Ljunggren, J. (2006). Delivery Performance: How to Define \& Measure Delivery Performance in a Triadic Relationship. https://www.diva-portal.org/smash/record.jsf?pid=diva2\%3A207312\&dswid=3940

Hondoko, L. P. (2016). The Effect of Product Quality and Delivery Service on Online-Customer Satisfaction in Zalora Indonesia. Jurnal EMBA, 4, 1189-1199.

Hong, L. M., Farha, W., Zulkifli, W., \& Hamsani, N. H. (2017). The Impact of Website Effectiveness towards Online Repurchase Intention. Journal of Entrepreneurship and 
Business, 5, 50-60. https://doi.org/10.17687/JEB.0502.05

Hulin, C., Netemeyer, R., \& Cudeck, R. (2001). Can a Reliability Coefficient Be Too High. Journal of Consumer Psychology, 10, 55-58. https://doi.org/10.1207/S15327663JCP1001\&2 05

Hult, G. T. M., Sharma, P. N., Morgeson, F. V., \& Zhang, Y. (2019). Antecedents and Consequences of Customer Satisfaction: Do They Differ Across Online and Offline Purchases? Journal of Retailing, 95, 10-23. https://doi.org/10.1016/j.jretai.2018.10.003

Kaňovská, L. (2010). Customer Services: A Part of Market Orientation. Economics and Management, 15, 562-565.

Kong, C., \& Chow, W. (2015). Journal of Air Transport Management On-Time Performance, Passenger Expectations and Satisfaction in the Chinese Airline Industry. Journal of Air Transport Management, 47, 39-47. https://doi.org/10.1016/j.jairtraman.2015.04.003

Lee, C., Park, N., \& Park, S. (2008). A Study on the Effects of Delivery Service Quality on Customer Satisfaction in Internet Apparel Shopping Mall. E-Trade Review, 6, 23-44. https://doi.org/10.17255/etr.6.2.200808.23

Liu, X., He, M., Gao, F., \& Xie, P. (2008). An Empirical Study of Online Shopping Customer Satisfaction in China: A Holistic Perspective. International Journal of Retail and Distribution Management, 36, 919-940. https://doi.org/10.1108/09590550810911683

Luo, J., Ba, S., \& Zhang, H. (2012). The Effectiveness of Online Shopping Characteristics and Well Designed Websites on Satisfaction. MIS Quarterly, 20, 1131-1144. https://doi.org/10.2307/41703501

Lysenko-Ryba, K. (2017). The Impact of Reverse Logistics on Customers Satisfaction Reverse Logistics Is One of Many Lines of Research in the Area of Supply Chain Manage. Przedsiębiorczość i Zarządzanie, 18, 137-146.

Martin, J., Mortimer, G., \& Andrews, L. (2015). Re-Examining Online Customer Experience to Include Purchase Frequency and Perceived Risk. Journal of Retailing and Consumer Services, 25, 81-95. https://doi.org/10.1016/j.jretconser.2015.03.008

Mentzer, J. T., Flint, D. J., \& Hult, G. T. M. (2001). Logistics Service Quality as a Segment-Customized Process. Journal of Marketing, 65, 82-104.

https://doi.org/10.1509/jmkg.65.4.82.18390

Odunlami, B. (2015). Impact of Customer Satisfaction on Customer Retention: A Case Study of a Reputable Bank in Oyo, Oyo State. Nigeria. International Journal of Managerial Studies and Research, 3, 42-53. https://www.arcjournals.org

Olasanmi, O. O. (2019). Online Shopping and Customers' Satisfaction in Lagos State, Nigeria. American Journal of Industrial and Business Management, 9, 1446-1463. https://doi.org/10.4236/ajibm.2019.96095

Pereira, H. G., Salgueiro, M. de F., \& Rita, P. (2016). Online Purchase Determinants of Loyalty: The Mediating Effect of Satisfaction in Tourism. Journal of Retailing and Consumer Services, 30, 279-291. https://doi.org/10.1016/j.jretconser.2016.01.003

Rahman, M. A., Islam, M. A., Esha, B. H., Sultana, N., \& Chakravorty, S. (2018). Consumer Buying Behavior towards Online Shopping: An Empirical Study on Dhaka City, Bangladesh. Cogent Business and Management, 5, 1-22.

https://doi.org/10.1080/23311975.2018.1514940

Rajendran, S. D., Wahab, S. N., Ling, Y. W., \& Yun, L. S. (2018). The Impact of Logistics Services on the e-Shoppers' Satisfaction. International Journal of Supply Chain Management, 7, 461-469.

Razak, I., Nirwanto, N., \& Triatmanto, B. (2016). The Impact of Product Quality and 
Price on Customer Satisfaction with the Mediator of Customer Value. Journal of Marketing and Consumer Research, 30, 59-68.

Revindran, M., Ragen, P. N. K., \& Mahmud, B. (2020). A Study on Logistics Service Quality in E-Retailing amongst Online Shoppers in Kuala Lumpur. IOP Conference Series: Materials Science and Engineering, 780, Article ID: 062016. https://doi.org/10.1088/1757-899X/780/6/062016

Rita, P., Oliveira, T., \& Farisa, A. (2019). The Impact of e-Service Quality and Customer Satisfaction on Customer Behavior in Online Shopping. Heliyon, 5, e02690. https://doi.org/10.1016/j.heliyon.2019.e02690

Rose, S., Clark, M., Samouel, P., \& Hair, N. (2012). Online Customer Experience in e-Retailing: An Empirical Model of Antecedents and Outcomes. Journal of Retailing, 88, 308-322. https://doi.org/10.1016/j.jretai.2012.03.001

Selvaraju, K., \& Karthikeyan, P. (2016). Impact on E-Commerce towards Online Shopping and Customer Buying Behavior. Asian Journal of Research in Social Sciences and Humanities, 6, 1260. https://doi.org/10.5958/2249-7315.2016.00511.6

Van Aswegen, A. S., \& Engelbrecht, A. S. (2009). The Relationship between Transformational Leadership, Integrity and an Ethical Climate in Organisations. SA Journal of Human Resource Management, 7, Article No. 175. https://doi.org/10.4102/sajhrm.v7i1.175

Vasic, N., Kilibarda, M., \& Kaurin, T. (2019). The Influence of Online Shopping Determinants on Customer Satisfaction in the Serbian Market. Journal of Theoretical and Applied Electronic Commerce Research, 14, 70-89. https://doi.org/10.4067/S0718-18762019000200107

Waari, D. (2019). The Effect of Customer Satisfaction on Customer Loyalty: The Moderation Roles of Experiential Encounter and Customer Patronage. SSRN Electronic Journal. https://doi.org/10.2139/ssrn.3393066

Yang, Y. H., Hui, Y. V., Leung, L. C., \& Chen, G. (2010). An Analytic Network Process Approach to the Selection of Logistics Service Providers for Air Cargo. Journal of the Operational Research Society, 61, 1365-1376. https://doi.org/10.1057/jors.2009.111

Yoon, S. H. (2011). The Influence of the Logistics Service Quality on Logistics Value, Customer Satisfaction, and Customer Loyalty of Internet Shopping Mall in China. Journal of International Area Studies, 15, 125. https://doi.org/10.18327/jias.2011.10.15.3.125

Zhang, M., Guo, L., Hu, M., \& Liu, W. (2017). Influence of Customer Engagement with Company Social Networks on Stickiness: Mediating Effect of Customer Value Creation. International Journal of Information Management, 37, 229-240. https://doi.org/10.1016/j.ijinfomgt.2016.04.010

Ziaullah, M., Feng, Y., \& Akhter, S. N. (2014). E-Loyalty: The Influence of Product Quality and Delivery Services on e-Trust and e-Satisfaction in China. International Journal of Advancements in Research \& Technology, 3, 20-31. 